\title{
Algoritma Scale Invariant Feature Transform (SIFT) pada Deteksi Kendaraan Bermotor di Jalan Raya
}

\section{YUSUP MIFTAHUDDIN, NUR FITRIANTI FAHRUDIN, MOCHAMAD FACHRY PRAYOGA}

\author{
Program Studi Informatika, Institut Teknologi Nasional Bandung \\ Email: yusufm@itenas.ac.id
}

Received 30 Maret 2020| Revised 30 April 2020 | Accepted 29 Mei 2020

\begin{abstract}
ABSTRAK
Proses perhitungan jumlah kendaraan yang masih dilakukan secara manual dan membutuhkan banyak operator dalam pendataan. Berdasarkan hal itu, diperlukan sistem yang mampu mendeteksi dan mengklasifikasi kendaraan yang melintas di jalan raya secara otomatis. Dalam mengidentifikasi citra kendaraan, sistem menggunakan algoritma SIFT. Hasil fitur akan dibandingkan dengan metode K-Nearest Neighbor (KNN). Sistem dibangun untuk mendeteksi jenis kendaraan berat dengan mengukur tingkat akurasi keberhasilan berdasarkan nilai pencahayaan, jumlah objek, perubahan rotasi, serta pada kondisi siang dan malam hari. Dataset yang digunakan berjumlah 100 citra kendaraan berat. Kinerja sistem pada kondisi siang hari mendapat nilai presisi rata-rata 100\%, nilai recall 54\%, dan nilai akurasi $78 \%$. Hasil pengukuran presisi dan recall, diperoleh nilai f-measure sebesar $67 \%$.
\end{abstract}

Kata kunci: SIFT, kendaraan berat, K-Nearest Neighbour

\begin{abstract}
The process of collecting vehicles still done manually and requires a lot of human resources. Therefore, we need a system that can detect and classify vehicles passing on the highway automatically. SIFT is an algorithm for identification of an image. The features will be compared using the K-Nearest Neighbor (KNN) method. In this study, system will be designed to detect the type of heavy vehicle using the SIFT method to measure the accuracy of success based on the value of lighting, number of objects, changes in rotation, and day night conditions. Dataset used was 100 heavy vehicle images. The system performance during daytime conditions gets an average precision value of $100 \%$, a recall value of $54 \%$, and an accuracy value of $78 \%$. From the results of precision and recall, the $f$-measure value is $67 \%$.
\end{abstract}

Keywords: SIFT, heavy vehicles, K-Nearest Neighbour 


\section{PENDAhULUAN}

Pada era modern saat ini, kemacetan adalah hal yang sering dijumpai terutama di kota metropolitan. Upaya yang dilakukan untuk mengurai kemacetan adalah dengan memanfaatkan data volume kendaraan yang melintas dijalan raya kemudian diolah untuk memantau kepadatan lalu lintas. Pada umumnya, proses pendataan jumlah kendaraan dilakukan dengan menghitung satu persatu kendaraan (Tarnoto, Lusiana, 2014). Sebagai contoh, ketika terjadi libur panjang khususnya hari raya Idul Fitri, banyak petugas yang ditugaskan untuk mengatur serta menghitung setiap kendaraan yang lewat dan mengklasifikasikannya. Perhitungan manual ini membutuhkan banyak sumber daya manusia yang harus turun ke lapangan.

Berdasarkan Pedoman Kapasitas Jalan Indonesia (PKJI, 2014), kendaraan tergolong menjadi 4, diantaranya kendaraan ringan (kendaraan yang beroda 4), kendaraan berat (kendaraan yang beroda lebih dari 4), sepeda motor (kendaraan beroda 2 atau 3) dan kendaraan tak bermotor (kendaraan dengan roda yang digerakkan oleh orang atau binatang).

Penelitian sebelumnya tentang deteksi dan klasifikasi kendaraan di jalan raya dilakukan oleh Alvin Lazaro pada tahun 2017 menggunakan metode Haar-like Feature yang menghasilkan tingkat akurasi hingga 77,8\% menggunakan citra rekaman video. Hal ini disebabkan adanya kesalahan pada klasifikasi yang disebabkan oleh faktor penskalaan objek kendaraan dimana kendaraan kecil terdeteksi menjadi kendaraan berat. Oleh karena itu, diperlukan pengembangan penelitian tersebut menggunakan metode lain untuk memperoleh tingkat akurasi yang lebih tinggi.

Al Kautsar dan Adi melakukan penelitian untuk mengembangkan sistem dengan menerapkan sensor RFID pada pendeteksian kendaraan dengan memiliki kelemahan pada detektor yang hanya dapat mendeteksi dengan keterbatasan jarak, dan biaya yang besar (Al Kautsar, Adi, 2016).

Wibowo, Muslim, Sarosa menerapkan deteksi tepi Canny pada proses segmentasi dan Fuzzy C-Means dalam menghitung kendaraan. Kontribusinya adalah pengambilan proses ekstraksi ciri dengan Canny (Wibowo, Muslim, Sarosa, 2013).

Adistya, Muslim melakukan penelitian untuk mengklasifikasi jenis kendaraan dan menghitung banyaknya kendaraan melalui citra. Kontribusi penelitian ini adalah penggunaan metode Backpropagation dalam mengenali dan mengklasifikasi golongan kendaraan berdasarkan panjang dan lebar di titik sudut kendaraan, serta melakukan ekstraksi ciri menggunakan Sobel (Adistya, Muslim, 2016).

Rosidin, Sugiantoro, Prayudi menerapkan SIFT dan histogram warna RGB dengan menghasilkan keakuratan yang lebih baik dalam menganalisa citra yang sudah diubah dari aslinya. (Rosidin, Sugiantoro, Prayudi, 2018).

Lionnie, Alaydrus melakukan percobaan menggunakan metode SIFT untuk mendeteksi pemalsuan pada gambar yang telah dimanipulasi dengan penyerangan jenis copy-move dan hasilnya dapat mendeteksi gambar yang telah di ubah arah dan ukurannya walaupun ada beberapa kecocokan yang salah (Lionnie, Alaydrus, 2017).

Pardede, Utami, Rochman mengkombinasikan algoritma Principal Componen Analysis dan SIFT untuk mengurangi dimensi pada citra (Pardede, Utami, Rochman, 2017). 
Lazaro, Buliali, Amaliah melakukan penelitian untuk membuat sebuah program yang mampu melakukan deteksi jenis kendaraan serta menghitung kendaraan yang terdeteksi berdasarkan jenisnya. Kontribusi penelitian ini adalah melakukan klasifikasi jenis kendaraan di jalan raya karena penelitian sebelumnya hanya melakukan deteksi objek kendaraan.

Berdasarkan pada penelitian-penelitian yang telah ada, penelitian ini menerapkan algoritma SIFT untuk mendeteksi kendaraan di jalan raya melalui kamera dengan jenis kendaraan yaitu kendaraan berat. Pengaruh pencahayaan objek yang diterima kamera pada saat pendeteksian akan diuji untuk mendapatkan hasil yang optimal. Algoritma SIFT dipilih karena bersifat lokal, khas, dan memiliki keunggulan dalam kuantitas, efesiensi, dan ekstensibilitas (Lowe, 2004).

Penelitian ini bertujuan untuk menghitung akurasi keberhasilan dari deteksi kendaraan berdasarkan jenis kendaraan berat dengan parameter pencahayaan pada kamera.

\section{METODE PENELITIAN}

\subsection{Perancangan Sistem}

Bagian ini memaparkan alur proses perancangan sistem pendeteksi objek kendaraan dengan menerapkan metode SIFT. Gambar 1 menunjukan alur kerja sistem secara keseluruhan.

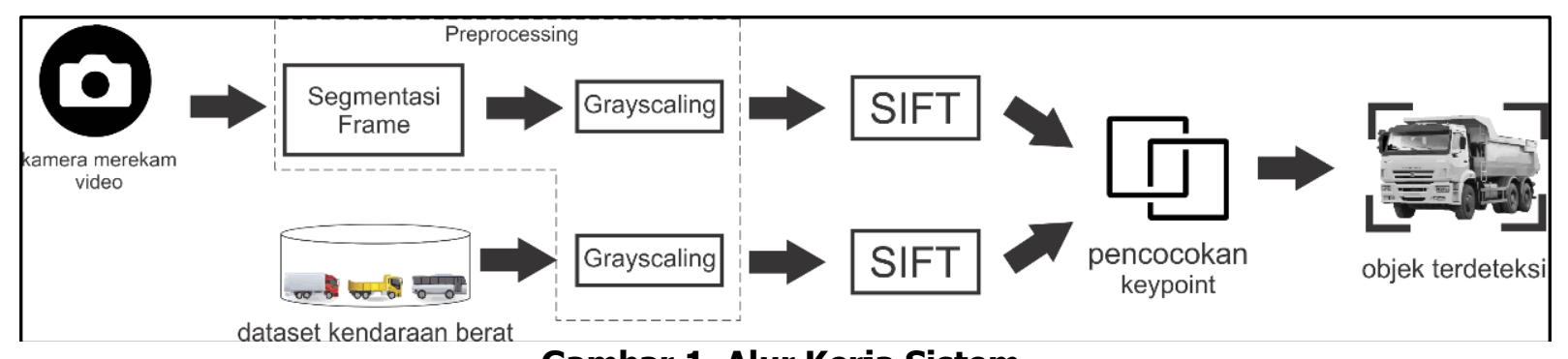

\section{Gambar 1. Alur Kerja Sistem}

Sistem yang dibangun adalah sistem deteksi kendaraan berdasarkan jenis kendaraan di jalan raya. Maka dari itu informasi pertama yang harus diketahui adalah citra kendaraan berdasarkan jenisnya yang dikumpulkan pada satu dataset. Sebelum dilakukan pencocokan, citra query didapatkan dari web kamera yang merekam video berupa frame. Algoritma SIFT digunakan untuk mengekstraksi fitur dari citra query dan citra latih pada dataset kendaraan yang sudah diklasifikasikan sebagai kendaraan berat kemudian dilakukan pencocokan keypoint antara kedua citra tersebut menggunakan $K$-Nearest Neighbour. Objek yang terdeteksi adalah kendaraan yang memiliki keypoint paling mirip kemudian objek akan ditandai dengan kotak berwarna hijau. 


\subsubsection{Proses Grayscale}

Berikut contoh matriks yang diambil dari data latih dengan ukuran $3 \times 3$.

\begin{tabular}{|c|c|c|}
\hline $\mathbf{( 0 , 0 )}$ & $\mathbf{( 0 , 1 )}$ & $\mathbf{( 0 , 2 )}$ \\
R: 98 & R: 96 & R: 90 \\
G: 155 & G: 153 & G: 148 \\
B: 176 & B: 173 & B: 167 \\
& & \\
\hline $\mathbf{( 1 , 0 )}$ & $\mathbf{( 1 , 1 )}$ & $\mathbf{( 1 , 2 )}$ \\
R: 99 & R: 96 & R: 91 \\
G: 155 & G: 153 & G: 148 \\
B: 176 & B: 173 & B: 167 \\
& & \\
\hline $\mathbf{( 2 , 0 )}$ & $\mathbf{( 2 , 1 )}$ & $\mathbf{( 2 , 2 )}$ \\
R: 100 & R: 98 & R: 92 \\
G: 155 & G: 153 & G: 148 \\
B: 176 & B: 173 & B: 167 \\
\hline
\end{tabular}

\begin{tabular}{|c|c|c|}
\hline $\mathbf{( 0 , 0 )}$ & $\mathbf{( 0 , 1 )}$ & $\mathbf{( 0 , 2 )}$ \\
145 & 142 & 137 \\
\hline $\mathbf{( 1 , 0 )}$ & $\mathbf{( 1 , 1 )}$ & $(\mathbf{1 , 2})$ \\
145 & 142 & 137 \\
\hline $\mathbf{( 2 , 0 )}$ & $\mathbf{( 2 , 1 )}$ & $\mathbf{( 2 , 2 )}$ \\
145 & 141 & 138 \\
\hline
\end{tabular}

Matriks Citra Grayscale

Matriks Citra RGB

Proses perhitungan untuk titik koordinat 1,1 :

Grayscale $=0.21 * 96+0.72 * 153+0.07 * 173$

Grayscale $=20.16+110.16+12.11$

Grayscale $=142.43=142$

\subsubsection{Scale Invariant Feature Transform (SIFT)}

Metode SIFT menemukan dan menjelaskan fitur lokal citra. Algoritma SIFT menghasilkan keypoint descriptor yang dapat dibandingkan antara satu citra dengan citra lainnya sehingga dapat menentukan kemiripan antara kedua citra tersebut. SIFT memiliki empat tahapan utama yaitu deteksi scale-space extrema, penentuan keypoint, Penetapan orientasi pada setiap keypoint, dan menghitung vektor deskriptor. Urutan proses tersebut ditampilkan oleh Gambar 2.

Skala ruang citra merupakan fungsi $L(x, y, \sigma)$ dihasilkan dari perhitungan konvolusi kernel Gaussian Blur dapat dilihat pada Persamaan 1 Proses deteksi puncak skala ruang dilakukan menggunakan fungsi Different of Gaussian pada Persamaan 2 untuk mengidentifikasi titiktitik yang potensial.

keterangan:

$$
\begin{aligned}
& G(x, y, \sigma)=\frac{1}{2 \pi \sigma^{2}} e^{-\left(x^{2}+y^{2}\right) / 2 \sigma^{2}} \\
& L(x, y, \sigma)=G(x, y, \sigma) * I(x, y) \\
& D(x, y, \sigma)=(L(x, y, k \sigma)-(L(x, y, \sigma)
\end{aligned}
$$

$$
\begin{array}{ll}
\mathrm{G}(\mathrm{x}, \mathrm{y}, \sigma)=\text { Gaussian Blur } & \pi=3,14 \\
\mathrm{I}(\mathrm{x}, \mathrm{y})=\text { Citra asli } & \sigma=3 \\
(\mathrm{~L}(\mathrm{x}, \mathrm{y}, \sigma)=\text { Gaussian Blur , } \mathrm{k}=\sqrt{ } 2 & \mathrm{e}=2,72 \text { (nilai ketetapan) }
\end{array}
$$

Proses penentuan keypoint dilakukan dengan mencari nilai maxima / minima DoG yang dideteksi dengan membandingkan sebuah piksel dengan tetangganya.

$$
\begin{gathered}
Z=-\left(\frac{\partial^{2} D}{\partial x^{2}}\right)^{-1} \frac{\partial D}{\partial x} \\
D(Z)=D+\frac{1}{2} \frac{\partial D^{-1}}{\partial x} Z
\end{gathered}
$$

Setelah ditemukan keypoint, selanjutnya proses penetapan orientasi pada setiap keypoint dengan cara mengumpulkan sudut gradien dan nilai disekitar keypoint .

$$
M(x, y)=\sqrt{(L(x+1, y)-L(x-1, y))^{2}+(L(x, y+1)-L(x, y-1))^{2}}
$$




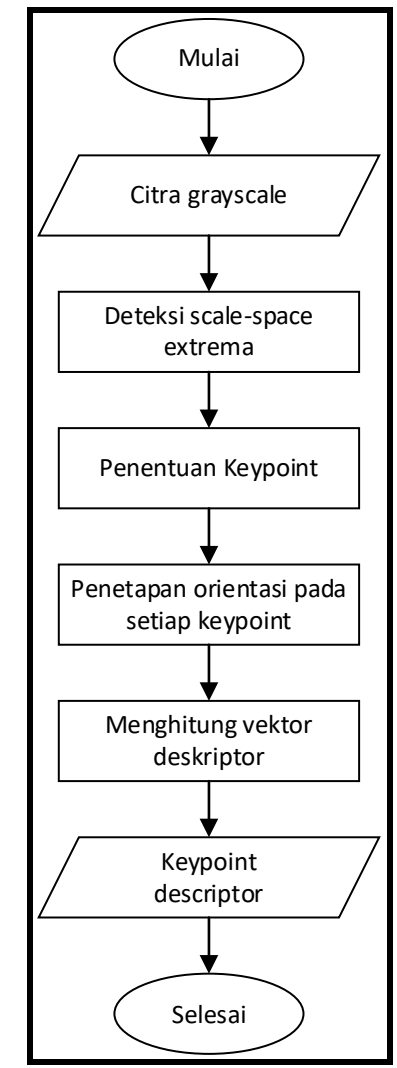

\section{Gambar 2. Diagram Alir SIFT}

Kemudian dicari orientasi yang unggul. Langkah terakhir adalah menghitung vektor deskriptor yang berujuan mencari invarian keypoint terhadap perubahan tingkat pencahayaan atau perubahan sudut pandang tiga dimensi sesuai Persamaan 7.

$$
\theta(x, y)=\tan ^{-1} \frac{L(x, y+1)-L(x, y-1)}{(L(x+1, y)-L(x-1, y)}
$$

\subsubsection{Scale Space Extrema Detection}

Contoh perhitungan pada titik koordinat $\mathrm{x}=1, \mathrm{y}=1$ dengan skala $\sigma=3, \pi=3.14$ dan $\mathrm{e}=$ 2.72 adalah:

$$
\begin{aligned}
& G(x, y, \sigma)=\frac{1}{2 \pi \sigma^{2}} e^{-\left(x^{2}+y^{2}\right) / 2 \sigma^{2}} \quad G(x, y, \sigma)=\frac{1}{2 * 3.14 * 1.6^{2}} 2.72^{-\left(1^{2}+1^{2}\right) / 2 * 1.6^{2}} \\
& G(x, y, \sigma)=0.0421
\end{aligned}
$$

Setelah didapatkan nilai Gaussian Blur sebesar 0.0421, kemudian dicari nilai scale space yang mempunyai nilai grayscale sebesar 142 dengan Persamaan 2.

$$
\begin{aligned}
& L(x, y, \sigma)=G(x, y, \sigma) * I(x, y) \\
& L(x, y, \sigma)=0.0421 * 142 \\
& L(x, y, \sigma)=5.97
\end{aligned}
$$

Berikut hasil perhitungan Gaussian Blur untuk setiap koordinat 


\begin{tabular}{|c|c|c|}
\hline $\mathbf{( 0 , 0 )}$ & $\mathbf{( 0 , 1 )}$ & $\mathbf{( 0 , 2 )}$ \\
9.02 & 7.42 & 4.13 \\
\hline $\mathbf{( 1 , 0 )}$ & $\mathbf{( 1 , 1 )}$ & $\mathbf{( 1 , 2 )}$ \\
7.26 & 5.97 & 3.30 \\
\hline $\mathbf{( 2 , 0 )}$ & $\mathbf{( 2 , 1 )}$ & $\mathbf{( 2 , 2 )}$ \\
3.90 & 3.21 & 1.80 \\
\hline
\end{tabular}

Selanjutnya untuk dapat menghitung nilai Different of Gaussian (DoG), diperlukan perhitungan nilai Gaussian blur dan skala ruang pada koordinat yang sama yaitu $(1,1)$ dengan skala $k \sigma$ dimana $k=\sqrt{ } 2$ dengan Persamaan berikut

$$
\begin{aligned}
& G(x, y, k \sigma)=\frac{1}{2 \pi(k \sigma)^{2}} e^{-\left(x^{2}+y^{2}\right) / 2(k \sigma)^{2}} \\
& G(x, y, k \sigma)=\frac{1}{2 * 3.14 *(\sqrt{2} * 1.6)^{2}} 2.72^{-\left(1^{2}+1^{2}\right) / 2 *(\sqrt{2} * 1.6)^{2}} \quad G(x, y, k \sigma)=0.0256
\end{aligned}
$$

\subsubsection{Keypoint Localization}

Masukan dari tahap ini adalah nilai DoG yang telah didapatkan pada perhitungan sebelumnya yaitu sebesar 2.34 pada posisi koordinat (1.1). Untuk menentukan posisi ekstremum dari keypoint dapat menggunakan Persamaan 4 dengan contoh perhitungan sebagai berikut:

$$
\begin{array}{ll}
Z=-\left(\frac{\partial^{2} D}{\partial x^{2}}\right)^{-1} \frac{\partial D}{\partial x} & Z=-(2.34)^{-1}+(2.34) \\
Z=-\left(\frac{\partial D}{\partial x} * x\right)^{-1} \frac{\partial D}{\partial x} & Z=-\frac{1}{2.34}(2.34) \\
Z=-(D * x) * x)^{-1}+(D * x) & Z=-\frac{2.34}{2.34} \\
Z=-(2.34 * 1) * 1)^{-1}+(2.34 * 1) & Z=-1
\end{array}
$$

Dengan demikian didapatkan hasil posisi ekstremum terletak pada nilai -1 . Kemudian dihitung nilai keypoint pada posisi ekstremum tersebut dengan menggunakan Persamaan 5 dimana nilai D adalah DoG sebesar 2.34 dan Z adalah nilai ekstremum sebesar -1 . Berikut adalah contoh perhitungan keypoint.

$$
D(Z)=D+\frac{1}{2} \frac{\partial D^{-1}}{\partial x} \mathrm{Z} \quad D(Z)=2.34+\frac{1}{2}\left(2.34^{-1} * 2\right)-1 \quad D(Z)=1.91
$$

\subsubsection{Penetapan Orientasi}

Penggunaan Gaussian smooth $\mathrm{L}$ dengan skala terdekat dengan skala keypoint. Pada sampel citra $L(x, y)$ hasil Gaussian Blur, magnitude $M(x, y)$ dihitung dengan menggunakan rumus Persamaan 6 dimana $x=1, y=1$ dan perhitungannya adalah 


$$
\begin{aligned}
& M(x, y)=\sqrt{(L(x+1, y)-L(x-1, y))^{2}+(L(x, y+1)-L(x, y-1))^{2}} \\
& M(x, y)=\sqrt{(L(1+1,1)-L(1-1,1))^{2}+(L(1,1+1)-L(1,1-1))^{2}} \\
& M(x, y)=\sqrt{(3.21-7.42)^{2}+(3.3-7.26)^{2}} \\
& M(x, y)=\sqrt{33.4057}=5.78
\end{aligned}
$$

\subsubsection{Keypoint Descriptor}

Untuk mencari keypoint descriptor, skala ruang pada citra $\mathrm{L}(\mathrm{x}, \mathrm{y})$ hasil Gaussian Blur dihitung menggunakan Persamaan 7 dimana $x=1$ dan $y=1$ dan perhitunganya adalah sebagai berikut.

$$
\begin{array}{ll}
\theta(x, y)=\tan ^{-1} \frac{L(x, y+1)-L(x, y-1)}{(L(x+1, y)-L(x-1, y)} & \theta(x, y)=\tan ^{-1} \frac{3.3-7.26}{3.21-7.42} \\
\theta(x, y)=\tan ^{-1} \frac{L(1,1+1)-L(1,1-1)}{(L(1+1,1)-L(1-1,1)} & \theta(x, y)=\tan ^{-1} 0.9406 \\
\theta(x, y)=0.7547 \text { atau } 43.25^{\circ}
\end{array}
$$

\section{HASIL DAN PEMBAHASAN}

\subsection{Pengujian Sistem}

Algoritma SIFT akan mengekstraksi fitur dari citra yang ditangkap oleh kamera (query) dengan keluaran berupa keypoint. Keypoint tersebut kemudian akan dicocokan dengan keypoint dari data latih. Gambar 3 menunjukkan keypoint yang dihasilkan dari citra kendaraan besar.

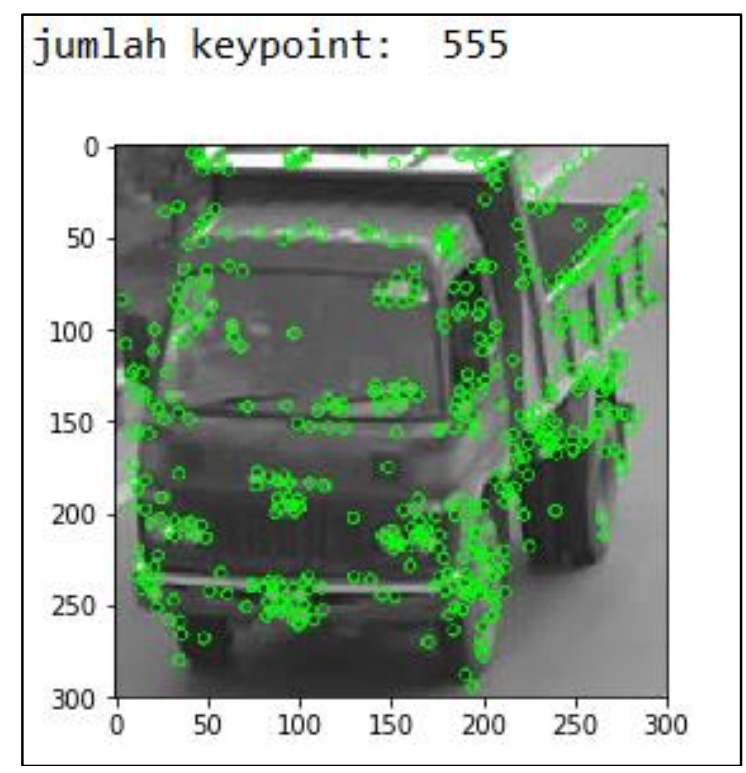

Gambar 1. Keypoint Citra

Jumlah keypoint yang dihasilkan dari suatu citra sangat banyak dan beragam sehingga pada pengujian ini akan dibatasi sebesar 50 keypoint yang akan dicocokan menggunakan metode KNN. 


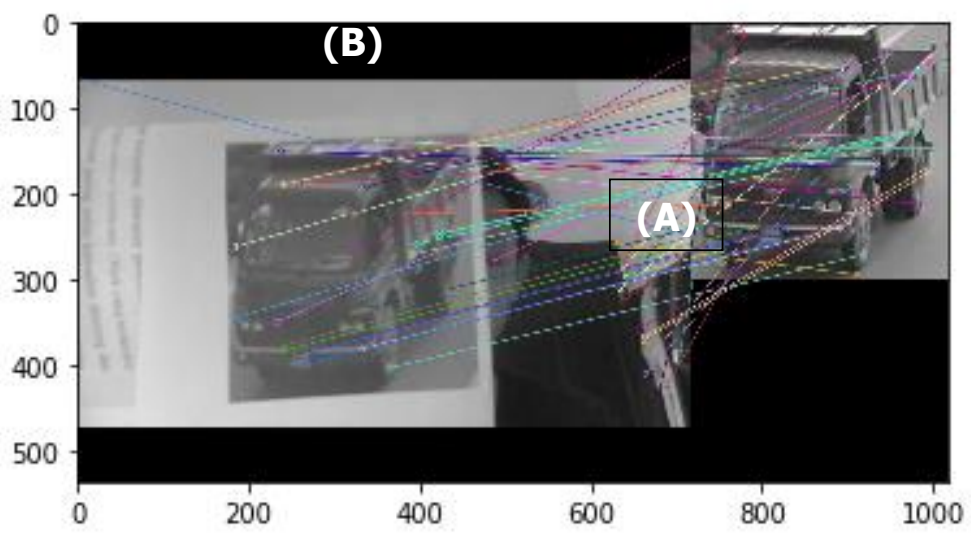

Gambar 2. Pencocokan Keypoint

Gambar 4 terdapat garis-garis yang menghubungkan antara citra dari data latih $(A)$ dan citra query (B) menunjukkan kecocokan antara keypoint kedua citra tersebut. Kemudian objek kendaraan citra query akan diberi tanda berupa kotak berwarna hijau seperti pada Gambar 5 .

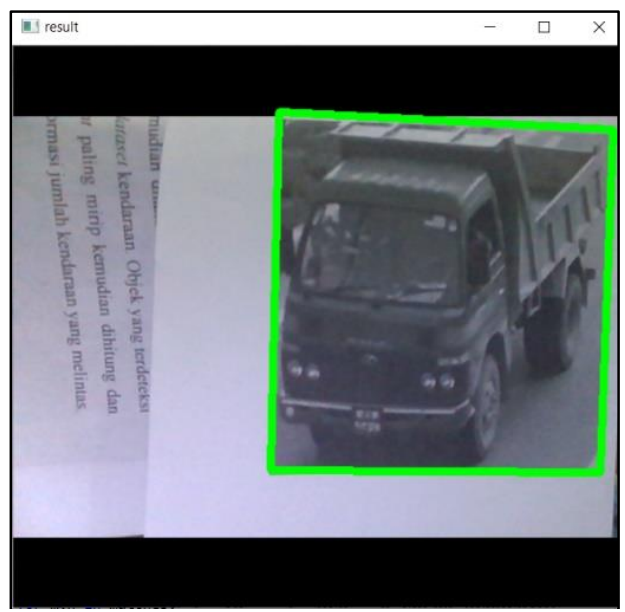

Gambar 3. Hasil Pencocokan

Pengujian dilakukan dengan citra yang memiliki 1, 2, 4, 6, dan 8 objek kendaraan berat yang berpengaruh terhadap ukuran objek yang akan dideteksi. Setiap pengujian dilakukan sebanyak 5 kali menggunakan parameter nilai pencahayaan (lux) dengan total pengujian 25 kali pada setiap parameter. Hasil dari pengujian ditunjukkan pada tabel berikut:

Tabel 1. Hasil Pengujian pada Pencahayaan 800 Lux

\begin{tabular}{|c|c|c|c|c|c|c|}
\hline No & Pengujian & $\begin{array}{c}\text { Pengujian } \\
\text { pertama }\end{array}$ & $\begin{array}{c}\text { Pengujian } \\
\text { kedua }\end{array}$ & $\begin{array}{c}\text { Pengujian } \\
\text { ketiga }\end{array}$ & $\begin{array}{c}\text { Pengujian } \\
\text { keempat }\end{array}$ & $\begin{array}{c}\text { Pengujian } \\
\text { kelima }\end{array}$ \\
\hline 1 & 1 Objek & $\begin{array}{c}1 \text { dari } 1 \\
\text { Terdeteksi }\end{array}$ & $\begin{array}{c}1 \text { dari } 1 \\
\text { Terdeteksi }\end{array}$ & $\begin{array}{c}1 \text { dari } 1 \\
\text { Terdeteksi }\end{array}$ & $\begin{array}{c}1 \text { dari } 1 \\
\text { Terdeteksi }\end{array}$ & $\begin{array}{c}1 \text { dari } 1 \\
\text { Terdeteksi }\end{array}$ \\
\hline 2 & 2 Objek & $\begin{array}{c}2 \text { dari } 2 \\
\text { Terdeteksi }\end{array}$ & $\begin{array}{c}2 \text { dari } 2 \\
\text { Terdeteksi }\end{array}$ & $\begin{array}{c}2 \text { dari } 2 \\
\text { Terdeteksi }\end{array}$ & $\begin{array}{c}2 \text { dari } 2 \\
\text { Terdeteksi }\end{array}$ & $\begin{array}{c}2 \text { dari } 2 \\
\text { Terdeteksi }\end{array}$ \\
\hline 3 & 4 Objek & $\begin{array}{c}4 \text { dari } 4 \\
\text { Terdeteksi }\end{array}$ & $\begin{array}{c}3 \text { dari } 4 \\
\text { Terdeteksi }\end{array}$ & $\begin{array}{c}4 \text { dari } 4 \\
\text { Terdeteksi }\end{array}$ & $\begin{array}{c}4 \text { dari } 4 \\
\text { Terdeteksi }\end{array}$ & $\begin{array}{c}4 \text { dari } 4 \\
\text { Terdeteksi }\end{array}$ \\
\hline 4 & 6 Objek & $\begin{array}{c}6 \text { dari } 6 \\
\text { Terdeteksi }\end{array}$ & $\begin{array}{c}4 \text { dari } 6 \\
\text { Terdeteksi }\end{array}$ & $\begin{array}{c}4 \text { dari } 6 \\
\text { Terdeteksi }\end{array}$ & $\begin{array}{c}3 \text { dari } 6 \\
\text { Terdeteksi }\end{array}$ & $\begin{array}{c}4 \text { dari } 6 \\
\text { Terdeteksi }\end{array}$ \\
\hline 5 & 8 Objek & $\begin{array}{c}5 \text { dari } 8 \\
\text { Terdeteksi }\end{array}$ & $\begin{array}{c}6 \text { dari } 8 \\
\text { Terdeteksi }\end{array}$ & $\begin{array}{c}7 \text { dari } 8 \\
\text { Terdeteksi }\end{array}$ & $\begin{array}{c}5 \text { dari } 8 \\
\text { Terdeteksi }\end{array}$ & $\begin{array}{c}6 \text { dari } 8 \\
\text { Terdeteksi }\end{array}$ \\
\hline
\end{tabular}


Tabel 1 menunjukkan hasil pengujian pendeteksian objek kendaraan berat dengan nilai pencahayaan 800lux. Nilai pencahayaan ini didapat dari aplikasi smartphone yang menggunakan sensor cahaya. Untuk mengukur akurasi dari pengujian diatas, jumlah nilai seluruh objek yang terdeteksi dibagi dengan total percobaan. Seperti pada Persamaan 8

$$
\text { Akurasi }=\frac{\text { Jumlah nilai seluruh objek yang terdeteksi }}{\text { total percobaan }}
$$

Setiap hasil yang terdeteksi sesuai dengan jumlah objek sebenarnya diberi nilai 1 . Sebagai contoh, pada pengujian ke 1, jumlah objek yang terdeteksi adalah 2 dari 2 yang diharapkan sehingga memiliki nilai 1 . Pada pengujian ke 4 dari 6 objek, jumlah objek yang terdeteksi adalah 3 dari 6 objek, sehingga memiliki nilai 0,5. Sedangkan objek bukan kendaraan berat yang tidak terdeteksi memiliki nilai 1 karena membuktikan bahwa sistem hanya mendeteksi jenis kendaraan berat.

Tabel 2. Nilai Pengujian

\begin{tabular}{|c|c|c|c|c|c|c|}
\hline No & Pengujian & $\begin{array}{c}\text { Pengujian } \\
\text { pertama }\end{array}$ & $\begin{array}{c}\text { Pengujian } \\
\text { kedua }\end{array}$ & $\begin{array}{c}\text { Pengujian } \\
\text { ketiga }\end{array}$ & $\begin{array}{c}\text { Pengujian } \\
\text { keempat }\end{array}$ & $\begin{array}{c}\text { Pengujian } \\
\text { kelima }\end{array}$ \\
\hline 1 & 1 Objek & 1,0 & 1,0 & 1,0 & 1,0 & 1,0 \\
\hline 2 & 2 Objek & 1,0 & 1,0 & 1,0 & 1,0 & 1,0 \\
\hline 3 & 4 Objek & 1,0 & 0,8 & 1,0 & 1,0 & 1,0 \\
\hline 4 & 6 Objek & 1,0 & 0,7 & 0,7 & 0,5 & 0,8 \\
\hline 5 & 8 Objek & 0,6 & 0,8 & 0,9 & 0,6 & 0,8 \\
\hline
\end{tabular}

Dari hasil pengujian pada Tabel 2, jumlah nilai dari seluruh objek yang terdeteksi adalah 11,97 kemudian dibagi dengan total 25 percobaan sehingga menghasilkan tingkat akurasi sebesar 0,879 atau $88 \%$. Pengujian selanjutnya adalah dengan mengubah nilai lux sebesar 50, 150, dan 400 yang hasillnya ditunjukkan pada Tabel 3.

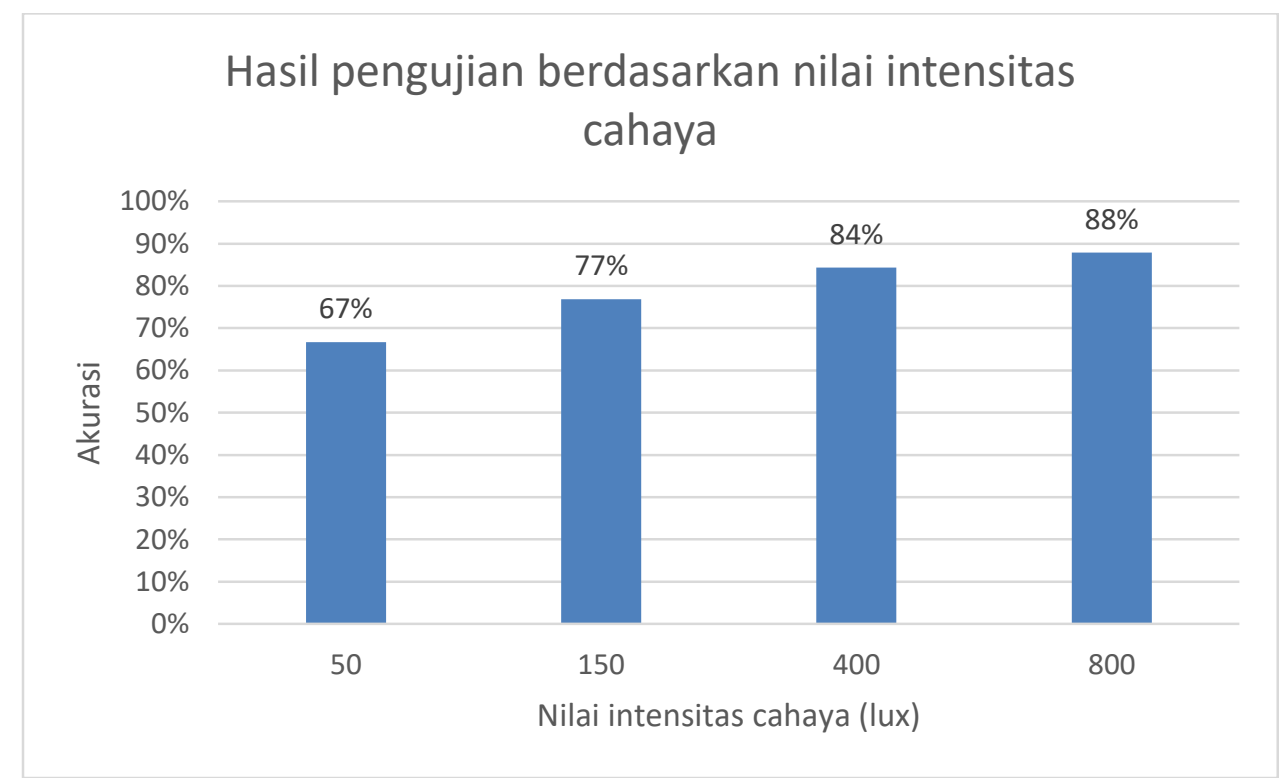

Gambar 6. Grafik Pengujian Berdasarkan Pencahayaan

Dari Gambar 6 dapat dilihat bahwa nilai pencahayaan yang lebih tinggi dapat menghasilkan tingkat akurasi yang lebih tinggi. Pada nilai pencahayaan yang rendah, terdapat noise pada 
hasil kamera yang mempengaruhi pencocokan sehingga objek yang buram tidak dapat terdeteksi.

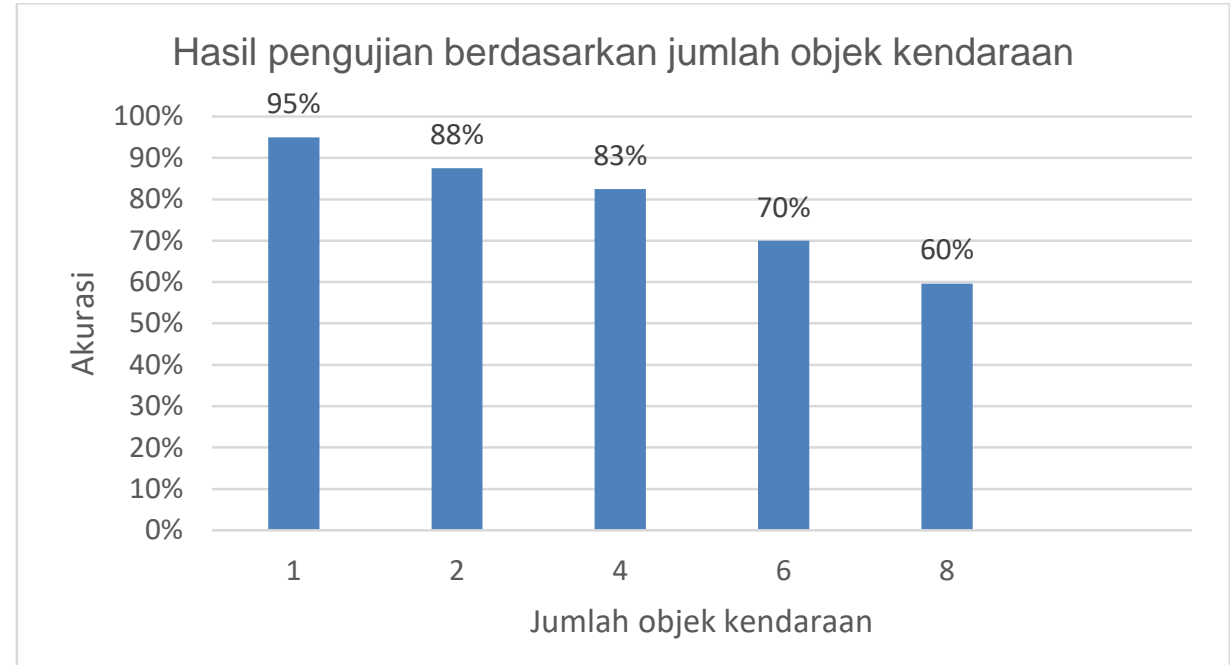

Gambar 7. Hasil Pengujian Berdasarkan Jumlah Objek Yang Dideteksi

Gambar 7 menunjukkan banyaknya objek juga mempengaruhi pendeteksian. Semakin banyak objek, semakin kecil akurasi yang dihasilkan. Banyaknya objek menyebabkan ukuran objek tersebut menjadi lebih kecil atau jarak yang lebih jauh sehingga dibutuhkan kamera dengan resolusi yang tinggi agar objek terlihat jelas. Dari hasil pengujian terhadap rotasi objek, terbukti bahwa algoritma SIFT ini tahan terhadap perubahan rotasi yang ditandai dengan terdeteksinya objek dengan kecocokan keypoint lebih dari 50 (nilai threshold) pada perubahan rotasi antara $0^{\circ}-180^{\circ}$ searah dan berlawanan jarum jam.

Untuk menguji kinerja sistem dilakukan pengujian deteksi kendaraan di jalan raya pada kondisi siang dan malam hari dan menghasilkan nilai recall $54 \%$, precision $100 \%$, accuracy $78 \%$, dan $f$-measure $67 \%$. Untuk lebih jelasnya dapat dilihat pada Tabel 3.

Tabel 3. Pengujian Pada Kondisi Siang Hari

\begin{tabular}{|c|c|c|c|c|c|c|c|c|c|}
\hline No & Pengujian & TP & TN & FP & $\mathbf{F N}$ & Recall & Precision & Accuracy & F1 \\
\hline 1 & Gambar 1 & 5 & 10 & 0 & 3 & $63 \%$ & $100 \%$ & $83 \%$ & $77 \%$ \\
\hline 2 & Gambar 2 & 2 & 13 & 0 & 1 & $67 \%$ & $100 \%$ & $94 \%$ & $80 \%$ \\
\hline 3 & Gambar 3 & 1 & 8 & 0 & 5 & $17 \%$ & $100 \%$ & $64 \%$ & $29 \%$ \\
\hline 4 & Gambar 4 & 3 & 9 & 0 & 5 & $38 \%$ & $100 \%$ & $71 \%$ & $55 \%$ \\
\hline 5 & Gambar 5 & 1 & 0 & 0 & 0 & $100 \%$ & $100 \%$ & $100 \%$ & $100 \%$ \\
\hline 6 & Gambar 6 & 1 & 2 & 0 & 2 & $33 \%$ & $100 \%$ & $60 \%$ & $50 \%$ \\
\hline 7 & Gambar 7 & 2 & 21 & 0 & 1 & $67 \%$ & $100 \%$ & $96 \%$ & $80 \%$ \\
\hline 8 & Gambar 8 & 4 & 2 & 0 & 4 & $50 \%$ & $100 \%$ & $60 \%$ & $67 \%$ \\
\hline \multicolumn{6}{|c|}{ Rata-rata } & $54 \%$ & $100 \%$ & $78 \%$ & $67 \%$ \\
\hline
\end{tabular}


Sistem tidak dapat mendeteksi kendaraan pada kondisi malam hari disebabkan kurangnya jumlah pencahayaan dan cahaya yang dikeluarkan oleh kendaraan menyebabkan kamera tidak dapat menangkap objek kendaraan dengan jelas. Hal ini berbanding lurus dengan pengujian sistem terhadap nilai pencahayaan yang telah dilakukan pada tahap sebelumnya

\section{KESIMPULAN}

Pada penelitian ini telah dipaparkan bagaimana penerapan algoritma Scale Invariant Feature Transform (SIFT) dalam mendeteksi kendaraan berat. Tahapan utama dari sistem pendeteksian ini adalah melakukan ekstraksi fitur pada citra uji dan kumpulan citra pada dataset menggunakan SIFT untuk mendapatkan keypoint dari setiap citra. Keypoint dari citra uji akan dicocokan dengan keypoint dari citra pada dataset menggunakan K-Nearest Neighbors (K-NN) untuk mendapatkan tingkat kemiripan yang tinggi. Hasil pengujian menunjukan bahwa nilai pencahayaan berpengaruh pada pendeteksian objek dengan pencahayaan optimal pada 800 lux atau pada kondisi siang hari. Semakin banyak jumlah objek yang akan dideteksi semakin kecil pula ukuran objek tersebut dan menyebabkan objek kurang terlihat jelas oleh kamera. Sedangkan posisi objek yang dirotasi searah sumbu $\mathrm{x}$ tetap terdeteksi sehingga tidak berpengaruh terhadap pendeteksian karena keypoint descriptor yang dihasilkan algoritma SIFT tahan terhadap perubahan posisi benda. Berdasarkan hasil pengujian kinerja sistem pada kondisi siang hari, nilai accuracy yang didapatkan sebesar $78 \%$, precision $100 \%$, recall $54 \%$ dan f-measure $67 \%$. Sedangkan pada kondisi malam hari, sistem tidak dapat mendeteksi objek dikarenakan kurangnya nilai pencahayaan. Hasil pengujian sistem tersebut menunjukan bahwa sistem berhasil mendeteksi hanya kendaraan berat, namun tidak dapat mendeteksi kendaraan berat yang terhalang oleh kendaraan lain.

\section{DAFTAR RUJUKAN}

Adistya, R., \& Muslim, M. A. (2016). Deteksi dan Klasifikasi Kendaraan menggunakan Algoritma Backpropagation dan Sobel. Journal of Mechanical Engineering and Mechatronics, 1(2), 65-73.

Al Caruban, R., Sugiantoro, B., \& Prayudi, Y. (2018). Analisis Pendeteksi Kecocokan Objek

Pada Citra Digital Dengan Metode Algoritma Sift Dan Histogram Color Rgb. Cyber Security dan Forensik Digital, 1(1), 20-27.

Al Kautsar, H. V., \& Adi, K. (2016). Implementasi Object Tracking Untuk Mendeteksi Dan

Menghitung Jumlah Kendaraan Secara Otomatis Menggunakan Metode Kalman Filter

Dan Gaussian Mixture Model. Youngster Physics Journal, 5(1), 13-20.

Husada, M. G., Utami, D. B., \& Zar, I. (2019). Karakteristik Metode Sift dalam Aplikasi Sistem

Pengenalan Motif Batik. MIND Journal, 4(2), 122-131.

Kadir, A., \& Susanto, A. (2013). Teori dan aplikasi pengolahan citra. Yogyakarta: Andi.

Kementerian Pekerjaan Umum. (2014). Pedoman Kapasitas Jalan Perkotaan.

Lionnie, R., \& Alaydrus, M. (2017). Sistem Pendeteksi Gambar Termanipulasi Menggunakan

Metode SIFT. Techné: Jurnal IImiah Elektroteknika, 16(02), 133-140. 
Algoritma Scale Invariant Feature Transform (SIFT) pada Deteksi Kendaraan Bermotor di Jalan Raya

Lowe, D. G. (2004). Distinctive image features from scale-invariant keypoints. International journal of computer vision, 60(2), 91-110.

Susanto, A. (2019). Penerapan Operasi Morfologi Matematika Citra Digital Untuk Ekstraksi Area Plat Nomor Kendaraan Bermotor. Pseudocode, 6(1), 49-57.

Tarnoto, T., \& Lussiana, L. (2014). Rancang Bangun Penghitung Kendaraan Secara Otomatis Berbasis Client Server. Jurnal IImiah IImu Komputer Program Studi Sistem Komputer.

Wibowo, D. W., Muslim, M. A., \& Sarosa, M. (2014). Perhitungan Jumlah dan Jenis Kendaraan Menggunakan Metode Fuzzy C-means dan Segmentasi Deteksi Tepi Canny. Jurnal EECCIS, $7(2), 103-110$. 